\title{
THE EFFECT OF HEALTH EDUCATION ON THE INTEREST OF WOMEN OF REPRODUCTIVE AGE IN PERFORMING A VISUAL INSPECTION OF ACETIC ACID
}

\author{
Diana Ode1,2) \\ 1)Universitas Respati, Yogyakarta \\ ${ }^{2)}$ Masters Program in Public Health, Universitas Sebelas Maret
}

\begin{abstract}
Background : Cervical cancer is the second most common cancer next to breast cancer. Despite the high burden of the disease and availability of free screening services, uptake is still trivial. This study aims to identify the effect of health education on the interest of women of reproductive age in performing a visual inspection of acetic acid (VIA).

Subjects and Method: A quasy experiment with no control group was conducted at Moro Bangun village, Sleman, Yogyakarta, Indonesia, in July 2019. A sample of 58 women of reproductive age was selected by purposive sampling. The dependent variable was interest to VIA uptake. The independent variable was health education. Interest to VIA uptake was measured by questionnaire. Mean of interest to VIA uptake before and after intervention was assessed by paired t-test.

Results: Mean score of interest to VIA uptake after health education intervention (Mean= 81.5; $\mathrm{SD}=7.77)$ was higher than before $(\mathrm{Mean}=69.29 ; \mathrm{SD}=7.91)$, with $\mathrm{p}<0.001$.
\end{abstract}

Conclusion: Health education improves interest to VIA uptake in women of reproductive age.

Keywords: health education, interest, visual inspection acetic acid, women of reproductive age

\section{Correspondence:}

Diana Ode. Masters Program in Public Health, Universitas Sebelas Maret. Jl. Ir. Sutami 36A, Surakarta 57126, Central Java. Email: Dianaodef161@gmail.com. Mobile: o85395912173. 